\title{
Cell surface cathepsin $G$ can be used as an additional marker to distinguish $T$ cell subsets
}

\author{
ADRIANE PENCZEK ${ }^{1}$ and TIMO BURSTER ${ }^{2}$ \\ ${ }^{1}$ Department of Neurosurgery, Ulm University Medical Center, D-89081 Ulm, Germany; ${ }^{2}$ Department of Biology, \\ School of Science and Technology, Nazarbayev University, Astana 010000, Republic of Kazakhstan
}

Received September 17, 2018; Accepted February 12, 2019

DOI: $10.3892 /$ br.2019.1198

\begin{abstract}
The serine protease cathepsin $\mathrm{G}(\mathrm{CatG})$ is involved in numerous processes associated with the innate and adaptive immune system. During an immune response, neutrophils secrete CatG, which can bind to the cell surface of immune cells to provoke the proteolytic processing of cytokines and chemokines in order to stimulate lymphocytes. The present study analyzed peripheral blood mononuclear cells to characterize $\mathrm{T}$ cell populations in terms of their CatG content by flow cytometry. It was identified that $\mathrm{CatG}$ was exclusively present on the cell surface of a subset of T regulatory cells (Tregs), cluster of differentiation (CD) $39^{+}$Tregs, which expressed CatG in contrast to CD39- Tregs. Additionally, CatG was expressed on double positive $\mathrm{CD} 4^{+} \mathrm{CD}^{+} \mathrm{T}$ cells, $\mathrm{T}$ helper $(\mathrm{Th})$ 9 cells and Th22 cells, implicating CatG as a novel marker to distinguish certain $\mathrm{T}$ cell subsets.
\end{abstract}

\section{Introduction}

Organisms are constantly exposed to diverse and harmful factors. As they are exposed to a surrounding environment containing bacteria, viruses and fungi, in addition to multicellular parasites, it is important that complex organisms develop efficient and specialized defense mechanisms. The innate immune system, which includes neutrophils, acts as the first line of contact against potential pathogens. By contrast, B cells, cytotoxic T lymphocytes and cluster of

Correspondence to: Professor Timo Burster, Department of Biology, School of Science and Technology, Nazarbayev University, 53 Kabanbay Batyr Avenue, Astana 010000, Republic of Kazakhstan E-mail: timo.burster@nu.edu.kz

Abbreviations: APCs, antigen-presenting cells; Cat, cathepsin; CatG, cathepsin G; DCs, dendritic cells; ECM, extracellular matrix; LF, lactoferrin; MFI, mean fluorescence intensity; MHC, major histocompatibility complex; NK cells, natural killer cells; PBMCs, peripheral blood mononuclear cells; SDF-1, stromal cell-derived factor 1; Th, T helper; Tregs, T regulatory cells

Key words: cathepsin G, proteases, T regulatory cells, CD39+ Tregs differentiation (CD) $4^{+} \mathrm{T}$ cells represent the majority of immune cells within the adaptive immune system, which is characterized by different properties, including a variety of antigen-specific receptors ( $\mathrm{B}$ and $\mathrm{T}$ cell receptors) and immunological memory (1). Antigenic peptides loaded to major histocompatibility complex (MHC) class I molecules are detected by $\mathrm{CD}^{+} \mathrm{T}$ cells; whereas macrophages, dendritic cells (DCs) and B cells, as professional antigen-presenting cells (APCs), display antigenic peptides to MHC II molecules, leading to $\mathrm{CD}^{+} \mathrm{T}$ cell activation when foreign antigens are recognized by these cells (2). $\mathrm{CD} 4^{+} \mathrm{T}$ cells are capable of differentiating into several types of $\mathrm{T}$ helper (Th) cells, including Th1, Th2, Th9, Th17 and Th22 cells, and execute distinct effector functions during an immune response (1). For example, Th1 cells detect intracellular pathogen-derived antigens, Th2 and Th9 cells defend against parasites, Th17 cells recognize fungi and extracellular bacteria, and Th22 cells serve as a defense against microbial infections of the skin (3-5).

$\mathrm{T}$ regulatory cells (Tregs) are essential for maintaining an immune response, immune homeostasis, and tolerance. Approximately $5 \%$ of $\mathrm{CD}^{+} \mathrm{T}$ cells are Tregs in normal human peripheral blood. Tregs are divided into thymus-derived natural Tregs, induced Tregs generated by transforming growth factor- $\beta$ and interleukin (IL)-2 in vitro, and peripheral Tregs (6). CD $39^{+}$Tregs express the ectonucleotidases CD39 and CD73; CD39 hydrolyzes extracellular ATP and ADP to generate AMP, and CD73 further converts AMP to adenosine, which binds to cell surface A2A receptor of effector cells and thereby suppresses a $\mathrm{T}$ cell response (7-10). Notably, antigen-specific Tregs express the co-stimulatory molecule CD134 (11,12).

Cathepsin $\mathrm{G}$ (CatG) belongs to the family of serine proteases. Due to the structural properties of the active center, which contains a catalytic triad consisting of histidine, aspartate and serine amino acids (13), CatG exhibits chymotrypsin and trypsin-like enzymatic activity with a broad substrate specificity (14,15). CatG and lactoferrin (LF), among other serine proteases, are released by activated neutrophils during an immune response (16). Of note, a previous study by our group identified that LF increased the activity of CatG and lowered its substrate specificity, and the combined action of LF and CatG increased the activation status of human platelets (17). Furthermore, CatG exhibit an antibacterial capacity, 
indicated by the positive charge of sufficient arginine residues within the CatG protein sequence (18) and is a component of the so-called neutrophil extracellular traps, as CatG has, compared with other serine proteases, a notably high affinity towards deoxyribonucleic acid $(19,20)$. In addition to the activation of specific cytokines to modulate an immune response, CatG is able to inactivate cytokines, including IL-2 and IL 6 , and the growth and maturation factor CXC chemokine stromal cell-derived factor 1 (SDF1) (21). Additionally, CatG has been detected on the cell surface of different immune cells, namely neutrophils (22), B cells, natural killer (NK) cells (23) and platelets (24), and low levels of CatG have been detected on $\mathrm{CD}^{+} \mathrm{T}$ cells (23). Previously, our group demonstrated that distinct $\mathrm{NK}$ cell subsets $\left(\mathrm{CD} 16^{-} \mathrm{CD} 56^{\mathrm{dim}}\right.$ and $\mathrm{CD}^{\mathrm{dim}} \mathrm{CD}^{\mathrm{C}} 6^{-}$) possessed proteolytic active $\mathrm{CatG}$ on their cell surface in contrast to other NK cell subsets (CD16 CD56 $6^{\text {bright }}$, CD16 ${ }^{\text {dim }}$ CD56 $6^{\text {bright }}, \mathrm{CD} 16^{\text {bright }}$ CD56 ${ }^{\text {dim }}, \mathrm{CD} 16^{\mathrm{dim}} \mathrm{CD} 56^{\mathrm{dim}}$, and CD16 ${ }^{\text {bright }}$ CD56-) (25). However, which $\mathrm{T}$ cell subsets carry CatG, and whether CatG can be detected on Tregs, was not determined. Therefore, the present study analyzed peripheral blood mononuclear cells (PBMCs) for their cell surface CatG content, and identified that $\mathrm{CD} 4^{+} \mathrm{CD} 8^{+} \mathrm{T}$ cells, Th9 cells, Th22 cells and CD39+ ${ }^{+}$Tregs, but not CD39- Tregs, harbored CatG at the cell surface, implicating CatG as a novel marker for these cells.

\section{Materials and methods}

Sample collection and preparation. Freshly purified or cryopreserved PBMCs from healthy male or female donors, young donors between 18-25 years and elderly donors between 59-70 years (collected between 2015 and 2016; gender ratio: female:male, 50:50), were analyzed. The PBMCs from buffy coats, obtained from the DRK Blood Donation Center, Baden-Württemberg-Hessen; Institute Ulm (Ulm, Germany), were purified using Ficoll density centrifugation (Ficoll-Pague PLUS, GE Healthcare, Little Chalfont, UK). The blood donors were informed with regard to the use of their blood cells for research purposes and their consent was obtained. Briefly, $25 \mathrm{ml}$ of a 1:10 phosphate-buffered saline (PBS, pH 7.4, Gibco; Thermo Fisher Scientific, Inc., Waltham, MA, USA) buffy coat dilution was carefully added to the Ficoll solution $(15 \mathrm{ml})$, which was prepared in a $50-\mathrm{ml}$ centrifuge tube, and centrifuged (750 x g for $20 \mathrm{~min}$ at room temperature). Following centrifugation, PBMCs were cautiously collected from the Ficoll interface, washed three times with PBS, and prepared for flow cytometric analysis. In case of later usage of PBMCs, $1 \times 10^{7}$ cells were stored in fetal bovine serum (FBS, Gibco; Thermo Fisher Scientific, Inc.) with $10 \%$ dimethyl sulfoxide (DMSO, Serva Electrophoresis GmbH, Heidelberg, Germany) at $-80^{\circ} \mathrm{C}$.

Detection of CatG on the cell surface of different $T$ cell subsets. The cryopreserved PBMCs were thawed, washed twice with PBS and adjusted to a final concentration of $5 \times 10^{6} \mathrm{PBMCs} / \mathrm{ml}$. Subsequently, the PBMCs were stained with anti-CD25-APC $(4 \mu \mathrm{g} / \mathrm{ml}$; BC96; Thermo Fisher Scientific, Inc.), anti-CD4-APC/Cy7 (4 $\mu \mathrm{g} / \mathrm{ml}$; RPA-T4; BD Biosciences, Franklin Lakes, NJ, USA), anti-CD8-PerCP (4 $\mu \mathrm{g} / \mathrm{ml}$; SK1; BD Biosciences), anti-C-C-chemokine receptor type 10 (CCR10)-APC $(2.5 \mu \mathrm{g} / \mathrm{ml} ; 6588-5$; BioLegend, Inc., San Diego, CA, USA), anti-CD4-Alexa Fluor 700 (4 $\mu \mathrm{g} / \mathrm{ml}$; OKT4; eBioscience; Thermo Fisher Scientific, Inc.), anti-CD39-PerCP/Cy5.5 (2 $\mu \mathrm{g} / \mathrm{ml}$; A1; BioLegend, Inc.), anti-CD127-PE/Cy7 (4 $\mu \mathrm{g} / \mathrm{ml}$; A019D5; BioLegend, Inc.), anti-CD134-PE (4 $\mu \mathrm{g} / \mathrm{ml}$; Ber-ACT35; BioLegend, Inc.), anti-CD183-PE (5 $\mu \mathrm{g} / \mathrm{ml}$; G025H7; BioLegend, Inc.), anti-CD194-PerCP/Cy5.5 (2.5 $\mu \mathrm{g} / \mathrm{ml}$; L291H4; BioLegend, Inc.), anti-CD196-PE/Cy7 (5 $\mu \mathrm{g} / \mathrm{ml}$; G034E3; BioLegend, Inc.), anti-human CatG-FITC ( $2 \mu \mathrm{g} / \mathrm{ml}$; ABIN5565299; Acris Antibodies $\mathrm{GmbH}$, Herford, Germany), or isotype control for CatG $(2 \mu \mathrm{g} / \mathrm{ml}$; ABIN96440; Acris Antibodies GmbH). The PBMCs were diluted in PBS ( $\mathrm{pH} 7.4)$ containing $1 \%$ FBS and incubated with the respective antibody set for $30 \mathrm{~min}$ at $4^{\circ} \mathrm{C}$. Following incubation, the PBMCs were washed, collected by a FACSCanto II cytometer (BD Biosciences), and analyzed using FlowJo software version 7.6.5 (FlowJo LLC, Ashland, OR, USA). The compensation was performed using unstained and single stained PBMCs by using the respective antibody and was calculated using FACSDiva ${ }^{\mathrm{TM}}$ software (BD Biosciences). Flow cytometric analysis and antibody selection for the Th subsets were based on resources from Miltenyi Biotec, Inc. (http://www.miltenyibiotec.com/ /media/Files/ Navigation/Cel1\%20analysis/resources/App_note-20320_ Tcell_subsets_05_WEB.ashx).

Statistical analysis. Statistical analysis was performed with GraphPad Prism 6 (GraphPad Software, Inc., La Jolla, CA, USA). Data are presented as standard error of the median and statistical analysis was performed using one-way analysis of variance and the Bonferroni correction. The use of PBMCs for in vitro experiments was approved by the Ethics Committee of Ulm University (Ulm, Germany; proposal no. 327/14).

\section{Results}

CatG is present on double positive $C D 4^{+} C D 8^{+} T$ cells, Th9 cells and Th22 cells. Double positive $\mathrm{CD} 4^{+} \mathrm{CD} 8^{+} \mathrm{T}$ cells are present in small numbers in the peripheral blood $(26,27)$ and their function remains a source of debate; for example, these cells exhibit an antiviral activity (28) but have also been implicated in several pathological conditions, including autoimmunity $(29,30)$ and cancer $(31)$. To determine whether these cells express cell surface CatG, PBMCs were gated for $\mathrm{CD}^{+} \mathrm{T}$ cells, $\mathrm{CD} 4^{+} \mathrm{T}$ cells and double positive $\mathrm{CD} 4^{+} \mathrm{CD} 8^{+}$ $\mathrm{T}$ cells, and the levels of cell surface $\mathrm{CatG}$ were analyzed. CatG was not detected on the cell surface of $\mathrm{CD} 8^{+} \mathrm{T}$ cells, as illustrated in Fig. 1A and B. This is in accordance with previously published data demonstrating that CatG was absent on $\mathrm{CD}^{+} \mathrm{T}$ cells $(23,32)$. In contrast to the $\mathrm{CD} 8^{+} \mathrm{T}$ cells, CatG was identified on the cell surface of $\mathrm{CD}^{+} \mathrm{CD}^{+} \mathrm{T}$ cells and on $\mathrm{CD}^{+}{ }^{+} \mathrm{T}$ cells; however, the obtained data for $\mathrm{CD} 4^{+} \mathrm{T}$ cells did not reach statistical significance. These results correlate with previously published data indicating that only low levels of CatG can be detected on $\mathrm{CD}^{+}{ }^{+} \mathrm{T}$ cells (23). Collectively, these findings suggest that the cell surface expression of $\mathrm{CatG}$ differs between $\mathrm{CD}^{+} \mathrm{T}$ cell subsets and that only a subpopulation may be positive for CatG. To examine this further, a panel of Th subsets was analyzed. Subpopulations of Th1, Th2, Th9, Th17, and Th22 cells were distinguished by a combination of 
A

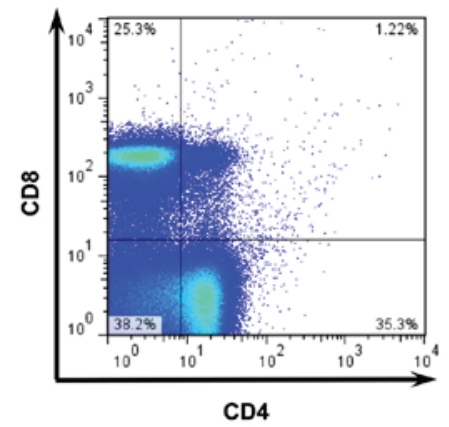

C

\begin{tabular}{|c|c|c|c|c|c|}
\hline Th subset & $\mathrm{CD} 4$ & CD183 & CD194 & CD196 & CCR10 \\
\hline Th1 & + & + & - & - & - \\
\hline Th2 & + & - & + & - & - \\
\hline The & + & 1 & - & + & 1 \\
\hline Th17 & + & - & + & + & - \\
\hline Th22 & + & - & + & + & + \\
\hline
\end{tabular}

E

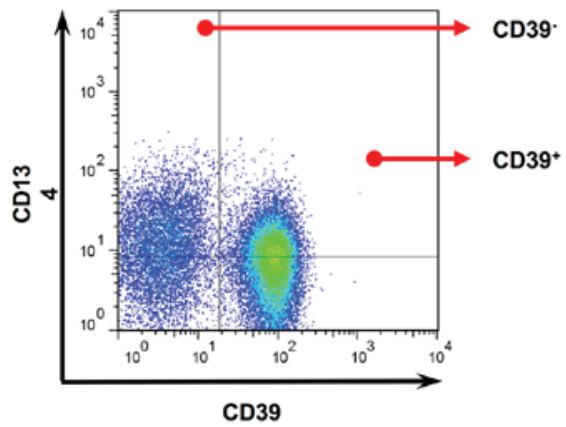

B

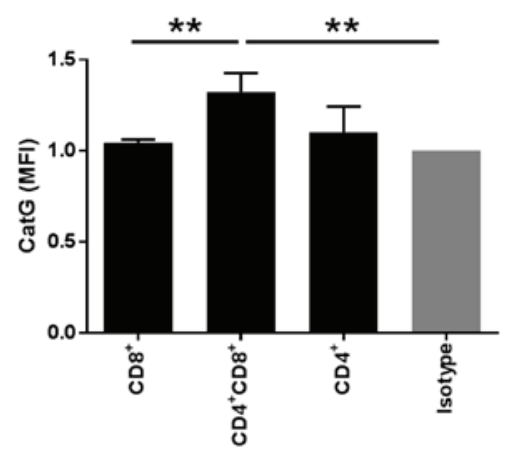

D

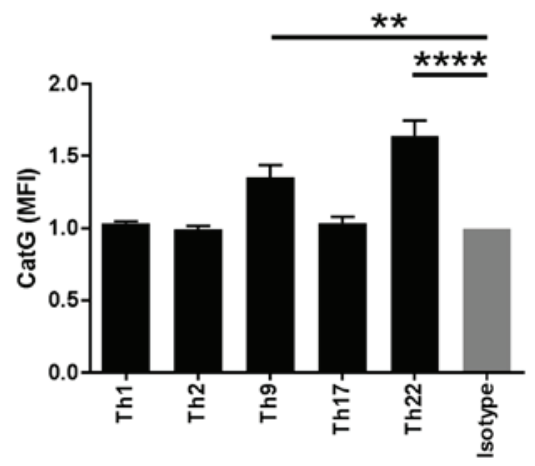

$\mathbf{F}$

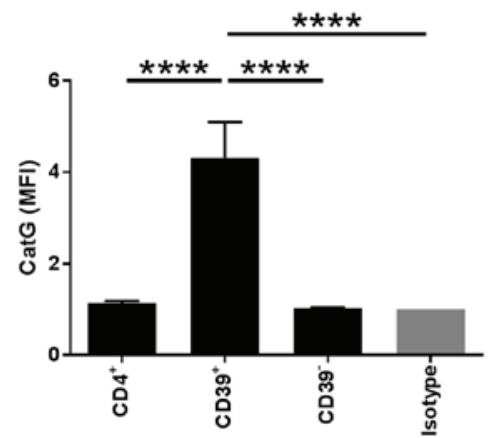

Figure 1. Analysis of CatG on the cell surface of PBMCs. (A) Cell populations were determined by the expression of CD4 and CD8 in combination with the expression of CatG. Double positive $\mathrm{CD} 4^{+} \mathrm{CD} 8^{+} \mathrm{T}$ cells, $\mathrm{CD} 4^{+} \mathrm{T}$ cells, and $\mathrm{CD} 8^{+} \mathrm{T}$ cells were detected and shown as one representative figure. (B) Expression levels of CatG on the indicated cells are summarized in the bar diagram (n=10). (C) Analysis of the activity of CatG on the cell surface of Th cell subsets. (D) Th1, Th2, Th9, Th17, and Th22 cells were detected, and cell surface expression of CatG was compared via flow cytometry. Th1 cells were deter-

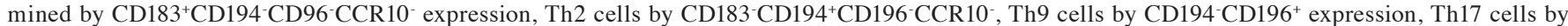
CD183 ${ }^{-} \mathrm{CD} 194^{+} \mathrm{CD} 196^{+} \mathrm{CCR} 10^{-}$expression, and Th22 cells by CD183 ${ }^{-} \mathrm{CD} 194^{+} \mathrm{CD} 196^{+} \mathrm{CCR} 10^{+}$expression $(\mathrm{n}=10)$. (E) Detection of CatG at the cell surface of Tregs. CD39- and CD39+ Tregs were compared for their cell surface expression of CatG by using flow cytometry. Cells were gated for CD127dimCD4 ${ }^{+} \mathrm{CD} 25^{+}$ and the remaining cells (CD39 vs. CD134) were split into Treg cell subsets (CD39- and CD39+ Tregs). (F) Levels of CatG on CD39- and CD39+ Tregs were analyzed in 37 healthy donors. For comparison, the MFI was used. The data were normalized to the isotype control and MFI values are expressed as the standard error of the median. Significant differences were calculated by one-way analysis of variance and the Bonferroni correction. ${ }^{* *} \mathrm{P}<0.01$ and ${ }^{* * * * *} \mathrm{P}<0.0001$. CatG, cathepsin G; CD, cluster of differentiation; CCR, C-C chemokine receptor; Th, Thelper; Tregs, T regulatory cells; MFI, median fluorescence intensity.

essential cell surface markers. An overview of the different antibodies used to identify Th subsets, namely CD4, CD183, CD194, CD196 and CCR10 antibodies, is shown in Fig. 1C. Notably, Th9 and Th22 cells carried cell surface CatG, whereas the analysis did not detect any CatG on Th1, Th2, or Th17 cells (Fig. 1D). Taken together, these findings suggest that CatG is present on the cell surface of double positive $\mathrm{CD} 4^{+} \mathrm{CD} 8^{+} \mathrm{T}$ cells, Th9 cells, and Th22 cells.

CatG is expressed on the cell surface of $C D 39^{+}$Tregs. Tregs are a heterogenic cell population. However, two subsets can be distinguished by their CD39 expression status, namely as
$\mathrm{CD}^{+} 9^{+}$and CD39- Tregs (11). The CD39+ ${ }^{+}$Treg subpopulation has a higher immune-suppressing capacity compared with CD39- Tregs $(8,9,33)$. In order to phenotype CD39+ ${ }^{+}$Tregs from viable singlets, cells were identified by an antibody panel recognizing cell surface CD4, CD127, CD25, CD134, and CD39 molecules (34). These CD ${ }^{+} \mathrm{T}$ cells, which exhibit a low expression of CD127 and high expression of CD25 (35), were further gated for $\mathrm{CD}_{134^{+}}$, and the two groups of $\mathrm{CD} 39^{-}$and CD39+ Tregs were investigated (data not shown). Notably, $\mathrm{CD} 9^{+}$Tregs did express CatG on the cell surface, whereas cell surface CatG was absent on CD39- cells (Fig. 1E and F). In addition, a small demographic donor group of $\mathrm{CD}^{3} 9^{+}$and 
CD39- Tregs was compared; however, no difference in the cell surface expression of CatG was observed when young and elderly donors were compared (data not shown). Taken together, these findings demonstrate that $\mathrm{CD} 39^{+}$Tregs harbor CatG on the cell surface, in contrast to CD39- Tregs.

\section{Discussion}

During an inflammatory response, neutrophils secrete CatG into the extracellular space to propagate innate and adaptive immune response (16). When simulating an immune response, a previous study indicated that exogenous CatG binds to $\mathrm{CD}^{+}$ T cells, $\mathrm{CD} 8^{+} \mathrm{T}$ cells, NK cells, and B cells (32). Although these findings were not determined for $\mathrm{CD} 8^{+} \mathrm{T}$ cells when excess quantities of CatG were added to the assay (23), the authors identified that the growth and maturation factor CXC chemokine SDF1, being key for an inflammatory response (21), was proteolytically inactivated by $\mathrm{Cat} G$ present on the cell surface of B cells, NK cells, and weakly on $\mathrm{CD}^{+} \mathrm{T}$ cells (23). The aforementioned results are of particular interest as Tregs are responsible for terminating an immune response (36). In turn, the data obtained in the present study suggest that cell surface CatG may support Treg cell function to maintain immune homeostasis.

In our previous study, it was demonstrated that DCs from CatG-deficient mice expressed lower levels of cell surface MHC I molecules compared with their wild-type counterparts. Furthermore, CatG provokes the upregulation of cell surface MHC I molecules on PBMCs and on human glioblastoma cells. Notably, cell surface CatG from PBMCs induces the expression of MHC I on the THP-1 monocytic cell line (37). In consideration of our previously published data and the finding that non-activated $\mathrm{CD} 4^{+} \mathrm{CD} 8^{+} \mathrm{T}$ cells expressed $\mathrm{CatG}$ on their cell surface, it may be hypothesized that $\mathrm{CD} 4^{+} \mathrm{CD} 8^{+} \mathrm{T}$ cells provoke an upregulation of MHC I on their target cell in order to monitor the intracellular peptide status via MHC I. In case of an altered MHC I-peptide repertoire, $\mathrm{CD} 4{ }^{+} \mathrm{CD} 8^{+} \mathrm{T}$ cells may act via their specialized function, which is potentially important for an immune response.

Migration and infiltration purposes of $\mathrm{CD} 4^{+} \mathrm{CD} 8^{+} \mathrm{T}$ cells, Th9 cells, Th22 cells, and CD $39^{+}$Tregs may be an additional reason for the presence of CatG at the cell surface. It is well known that matrix metalloproteinases are not the only essential enzymes in extracellular matrix (ECM) remodeling and cell migration; serine proteases, including $\mathrm{CatG}$, are also capable of degrading the ECM (38). It is possible that $\mathrm{CD} 4^{+} \mathrm{CD} 8^{+}$ $\mathrm{T}$ cells, Th9 cells, Th22 cells, and CD39+ Tregs reach their destination more efficiently than non-CatG expressing $\mathrm{T}$ cells. The significance of $\mathrm{CatG}$ on CD39+ ${ }^{+}$Tregs and its biological function can be analyzed by the application of a specific CatG inhibitor, potentially eliciting the modulation of T cell migration. The use of flow cytometry to detect CatG has limitations, additional methods are required in order to further examine CatG and its potential role in the support or regulation of an immune response.

In conclusion, the present study used a direct FITC-conjugated anti-CatG antibody to perform the assay, which was found to be advantageous for the rapid analysis of immune cells compared with the unconjugated anti-CatG antibody used in previous studies $(23,32)$. Furthermore, CatG may be considered as a novel cell surface marker of $\mathrm{CD} 4^{+} \mathrm{CD} 8^{+} \mathrm{T}$ cells, Th9 cells, Th22 cells, and CD39+ Tregs.

\section{Acknowledgements}

The authors would like to thank Professor Christian Rainer Wirtz, Department of Neurosurgery, Ulm University Medical Center, Ulm, Germany for his support in terms of laboratory space and reagents, and Professor Markus Huber-Lang, Ulm University Medical Center, Ulm, Germany for use of the flow cytometer (FACSCanto II).

\section{Funding}

No funding was received.

\section{Availability of data and materials}

All materials included in this manuscript can be made freely available to any researchers who wish to use them for non-commercial purposes.

\section{Authors' contributions}

AP performed the experiments and analyzed the data. TB designed the experiments and wrote the manuscript.

\section{Ethics approval and consent to participate}

Written informed consent was obtained from all participants and the study was approved by the Ethics Committee of Ulm University (Ulm, Germany, proposal no. 327/14).

\section{Patient consent for publication}

Written informed consent was obtained from all participants, which covered publication of the participants' data anonymously.

\section{Competing interests}

The authors declare that they have no competing interests.

\section{References}

1. Sallusto F: Heterogeneity of Human CD4(+) T Cells Against Microbes. Annu Rev Immunol 34: 317-334, 2016.

2. Blum JS, Wearsch PA and Cresswell P: Pathways of antigen processing. Annu Rev Immunol 31: 443-473, 2013.

3. Duhen T, Duhen R, Lanzavecchia A, Sallusto F and Campbell DJ: Functionally distinct subsets of human FOXP3+ Treg cells that phenotypically mirror effector Th cells. Blood 119: 4430-4440, 2012.

4. Luckheeram RV, Zhou R, Verma AD and Xia B: CD4+T cells: Differentiation and functions. Clin Dev Immunol 2012: 925135, 2012.

5. Mahnke YD, Beddall MH and Roederer M: OMIP-017: Human CD4(+) helper T-cell subsets including follicular helper cells. Cytometry A 83: 439-440, 2013.

6. Kanamori M, Nakatsukasa H, Okada M, Lu Q and Yoshimura A: Induced Regulatory T Cells: Their Development, Stability, and Applications. Trends Immunol 37: 803-811, 2016.

7. Mandapathil M, Hilldorfer B, Szczepanski MJ, Czystowska M, Szajnik M, Ren J, Lang S, Jackson EK, Gorelik E and Whiteside TL: Generation and accumulation of immunosuppressive adenosine by human CD4+CD25highFOXP3+ regulatory T cells. J Biol Chem 285: 7176-7186, 2010. 
8. Borsellino G, Kleinewietfeld M, Di Mitri D, Sternjak A Diamantini A, Giometto R, Höpner S, Centonze D, Bernardi G, Dell'Acqua ML, et al: Expression of ectonucleotidase CD39 by Foxp3+ Treg cells: Hydrolysis of extracellular ATP and immune suppression. Blood 110: 1225-1232, 2007.

9. Deaglio S, Dwyer KM, Gao W, Friedman D, Usheva A, Erat A, Chen JF, Enjyoji K, Linden J, Oukka M, et al: Adenosine generation catalyzed by CD39 and CD73 expressed on regulatory $\mathrm{T}$ cells mediates immune suppression. J Exp Med 204: $1257-1265,2007$.

10. Longhi MS, Moss A, Jiang ZG and Robson SC: Purinergic signaling during intestinal inflammation. J Mol Med (Berl) 95 915-925, 2017

11. Seddiki N, Cook L, Hsu DC, Phetsouphanh C, Brown K, $\mathrm{Xu}$ Y, Kerr SJ, Cooper DA, Munier CM, Pett S, et al: Human antigen-specific CD4(+) CD25(+) CD134(+) CD39(+) T cells are enriched for regulatory $\mathrm{T}$ cells and comprise a substantial proportion of recall responses. Eur J Immunol 44: 1644-1661, 2014.

12. Phetsouphanh C, Xu Y, Amin J, Seddiki N, Procopio F, Sekaly RP, Zaunders JJ and Kelleher AD: Characterization of transcription factor phenotypes within antigen-specific CD4+ $\mathrm{T}$ cells using qualitative multiplex single-cell RT-PCR. PLoS One 8: e74946, 2013.

13. Korkmaz B, Moreau T and Gauthier F: Neutrophil elastase, proteinase 3 and cathepsin G: Physicochemical properties, activity and physiopathological functions. Biochimie 90 227-242, 2008

14. Hof P, Mayr I, Huber R, Korzus E, Potempa J, Travis J, Powers JC and Bode W: The $1.8 \mathrm{~A}$ crystal structure of human cathepsin $\mathrm{G}$ in complex with Suc-Val-Pro-PheP-(OPh)2: A Janus-faced proteinase with two opposite specificities. EMBO J 15 5481-5491, 1996

15. Powers JC, Tanaka T, Harper JW, Minematsu Y, Barker L, LincolnD,CrumleyKV,FrakiJE,SchechterNM,LazarusGG, etal: Mammalian chymotrypsin-like enzymes. Comparative reactivities of rat mast cell proteases, human and dog skin chymases, and human cathepsin $\mathrm{G}$ with peptide 4-nitroanilide substrates and with peptide chloromethyl ketone and sulfonyl fluoride inhibitors. Biochemistry 24: 2048-2058, 1985.

16. Korkmaz B, Horwitz MS, Jenne DE and Gauthier F: Neutrophil elastase, proteinase 3 , and cathepsin $\mathrm{G}$ as therapeutic targets in human diseases. Pharmacol Rev 62: 726-759, 2010.

17. EipperS,SteinerR,LesnerA,SienczykM,PaleschD,Halatsch ME, Zaczynska E, Heim C, Hartmann MD, Zimecki M, et al: Lactoferrin Is an Allosteric Enhancer of the Proteolytic Activity of Cathepsin G. PLoS One 11: e0151509, 2016.

18. Bangalore N, Travis J, Onunka VC, Pohl J and Shafer WM: Identification of the primary antimicrobial domains in human neutrophil cathepsin G. J Biol Chem 265: 13584-13588, 1990

19. Brinkmann V, Reichard U, Goosmann C, Fauler B, Uhlemann Y, Weiss DS, Weinrauch Y and Zychlinsky A: Neutrophil extracellular traps kill bacteria. Science 303: 1532-1535, 2004

20. Thomas MP, Whangbo J, McCrossan G, Deutsch AJ, Martinod K, Walch $\mathrm{M}$ and Lieberman J: Leukocyte protease binding to nucleic acids promotes nuclear localization and cleavage of nucleic acid binding proteins. J Immunol 192: 5390-5397, 2014.

21. Luster AD: Chemokines - chemotactic cytokines that mediate inflammation. N Engl J Med 338: 436-445, 1998.
22. Owen CA, Campbell MA, Sannes PL, Boukedes SS and Campbell EJ: Cell surface-bound elastase and cathepsin G on human neutrophils: A novel, non-oxidative mechanism by which neutrophils focus and preserve catalytic activity of serine proteinases. J Cell Biol 131: 775-789, 1995.

23. Delgado MB, Clark-Lewis I, Loetscher P, Langen H, Thelen M, Baggiolini $M$ and Wolf $M$ : Rapid inactivation of stromal cell-derived factor-1 by cathepsin $\mathrm{G}$ associated with lymphocytes. Eur J Immunol 31: 699-707, 2001.

24. Selak MA: Cathepsin G and thrombin: Evidence for two different platelet receptors. Biochem J 297: 269-275, 1994.

25. Penczek A, Sienczyk M, Wirtz CR and Burster T: Cell surface cathepsin $\mathrm{G}$ activity differs between human natural killer cell subsets. Immunol Lett 179: 80-84, 2016.

26. Blue ML, Daley JF, Levine H and Schlossman SF: Coexpression of T4 and T8 on peripheral blood T cells demonstrated by two-color fluorescence flow cytometry. J Immunol 134: 2281-2286, 1985.

27. Ortolani C, Forti E, Radin E, Cibin R and Cossarizza A: Cytofluorimetric identification of two populations of double positive $(\mathrm{CD} 4+, \mathrm{CD} 8+) \mathrm{T}$ lymphocytes in human peripheral blood. Biochem Biophys Res Commun 191: 601-609, 1993.

28. Nascimbeni M, Shin EC, Chiriboga L, Kleiner DE and Rehermann B: Peripheral CD4(+)CD8(+) T cells are differentiated effector memory cells with antiviral functions. Blood 104: 478-486, 2004.

29. Bonomo A, Kehn PJ and Shevach EM: Premature escape of double-positive thymocytes to the periphery of young mice. Possible role in autoimmunity. J Immunol 152: 1509-1514, 1994.

30. Munschauer FE, Stewart C, Jacobs L, Kaba S, Ghorishi Z, Greenberg SJ and Cookfair D: Circulating CD3+ CD4+ CD8+ T lymphocytes in multiple sclerosis. J Clin Immunol 13: 113-118, 1993.

31. Mizuki M, Tagawa S, Machii T, Shibano M, Tatsumi E, Tsubaki K, Tako H, Yokohama A, Satou S, Nojima J, et al: Phenotypical heterogeneity of CD4+CD8+ double-positive chronic T lymphoid leukemia. Leukemia 12: 499-504, 1998.

32. Yamazaki $\mathrm{T}$ and Aoki Y: Cathepsin $\mathrm{G}$ binds to human lymphocytes. J Leukoc Biol 61: 73-79, 1997.

33. Dwyer KM, Deaglio S, Gao W, Friedman D, Strom TB and Robson SC: CD39 and control of cellular immune responses. Purinergic Signal 3: 171-180, 2007.

34. Schmetterer KG, Neunkirchner A and Pickl WF: Naturally occurring regulatory T cells: Markers, mechanisms, and manipulation. FASEB J 26: 2253-2276, 2012.

35. Seddiki N, Santner-Nanan B, Martinson J, Zaunders J, Sasson S, Landay A, Solomon M, Selby W, Alexander SI, Nanan R, et al: Expression of interleukin (IL)-2 and IL-7 receptors discriminates between human regulatory and activated T cells. J Exp Med 203: $1693-1700,2006$

36. Whiteside TL: Regulatory $\mathrm{T}$ cell subsets in human cancer: Are they regulating for or against tumor progression? Cancer Immunol Immunother 63: 67-72, 2014.

37. Giese M, Turiello N, Molenda N, Palesch D, Meid A, Schroeder R, Basilico P, Benarafa C, Halatsch ME, Zimecki M, et al: Exogenous cathepsin $\mathrm{G}$ upregulates cell surface MHC class I molecules on immune and glioblastoma cells. Oncotarget 7: 74602-74611, 2016.

38. Tan GJ, Peng ZK, Lu JP and Tang FQ: Cathepsins mediate tumor metastasis. World J Biol Chem 4: 91-101, 2013. 